\title{
TO STUDY THE LEVEL OF HIGH-SENSITIVE C-REACTIVE PROTEIN WITH ULTRASONOGRAPHIC FINDINGS AS A PREDICTIVE FACTOR FOR DIFFICULT LAPAROSCOPIC CHOLECYSTECTOMY
}

\author{
Purujit Choudhury1, Anjila Paul ${ }^{2}$ \\ ${ }^{1}$ Associate Professor, Department of Surgery, Gauhati Medical College, Assam. \\ 2Junior Resident, Department of Surgery, Gauhati Medical College, Assam.
}

\begin{abstract}
BACKGROUND

Laparoscopic cholecystectomy is considered to be the gold standard for the treatment of gallstones. However, conversion of laparoscopic cholecystectomy to open cholecystectomy is done by surgeons in difficult cases. The aim of the study is to use Hs-CRP level in correlation with ultrasonographic findings to predict difficult laparoscopic cholecystectomy pre-operatively. It would help in anticipating a difficult laparoscopic cholecystectomy pre-operatively, better counselling of patients, avoiding unnecessary laparoscopic dissection and hence less morbidity.
\end{abstract}

\section{MATERIALS AND METHODS}

This is an observational study. It is an original study conducted in the Department of General Surgery of Gauhati Medical College and Hospital. The study group included 40 consecutive patients undergoing laparoscopic cholecystectomy for cholelithiasis. Cholelithiasis was diagnosed on the basis of ultrasonography done pre-operatively. Hs-CRP level was determined pre-operatively and post-operatively after $6 \mathrm{hrs}$. and $12 \mathrm{hrs}$. It was correlated with ultrasonographic findings to predict difficult cholecystectomy.

\section{RESULTS}

The mean value of Hs-CRP was found to be $9.68 \mathrm{mg} / \mathrm{L}$ pre-operatively, $21.88 \mathrm{mg} / \mathrm{L}$ at 6 hours and $26.57 \mathrm{mg} / \mathrm{L}$ at $12 \mathrm{hours}$. While the mean value of Hs-CRP was found to be significantly higher in cases, which needed conversion. USG findings such as presence of adhesion, GB wall thickness more than $3 \mathrm{~mm}$ and narrow Calot's triangle were found to be significant predictors for conversion. On correlation, the positive predictive value increased.

\section{CONCLUSION}

Pre-operative values of Hs-CRP when combined with ultrasonography findings can predict difficult cholecystectomy. It will help in better selection of patients and help in decreasing morbidity.

\section{KEYWORDS}

Laparoscopic Cholecystectomy, HS-CRP, Ultrasonography, Conversion.

HOW TO CITE THIS ARTICLE: Choudhury P, Paul A. To study the level of high-sensitive C-reactive protein with ultrasonographic findings as a predictive factor for difficult laparoscopic cholecystectomy. J. Evolution Med. Dent. Sci. 2018;7(04):419-423, DOI: $10.14260 /$ jemds/2018/93

\section{BACKGROUND}

Gallstones are among the most common gastrointestinal illness requiring surgery. They are a major cause of morbidity and mortality throughout the world.[1] Laparoscopic cholecystectomy has been recognised as the gold standard for the treatment of gallstones.[2] Currently, it is estimated that over $75 \%$ of cholecystectomies are performed using laparoscopic approach.[3]

The advantages include earlier return of bowel function, less post-operative pain, improved cosmesis, shorter length of hospital stay, earlier return to full activity and decreased overall cost. $[3,4,5]$ However, very often surgeons face a number of surgical and technical difficulties while performing the procedure, due to which the procedure has to be converted into open cholecystectomy. The conversion rate for elective laparoscopy cholecystectomy varies from $2 \%-15 \%,[6,7,8]$ Inability to define the anatomy and difficult dissection are the

'Financial or Other Competing Interest': None.

Submission 15-12-2017, Peer Review 08-01-2018,

Acceptance 14-01-2018, Published 22-01-2018.

Corresponding Author:

Dr. Purujit Choudhury,

P. O. Gopinath Nagar, Arya Path,

Gauhati-781016, Assam.

E-mail:drpurujit@yahoo.in

DOI: $10.14260 /$ jemds/2018/93 leading reasons for conversion followed by other complications like bleeding. It has now become one of the most common operations performed by general surgeons. ${ }^{[9]}$

CRP is an acute phase reactant protein synthesised by the liver in response to factors released by macrophages and adipocytes in the face of inflammation. During the acute phase response, level of CRP rapidly increases within $2 \mathrm{hrs}$. of acute insult, reaching a peak at 48 hrs. CRP declines with a relatively short life of $19 \mathrm{hrs}$. The Hs-CRP assay is an advanced quantitative analysis using laser nephelometry. It can measure very low levels of C-reactive proteins. It has been shown to be more accurate in predicting risk of morbidity in undertaking lap cholecystectomy in normal people than standard CRP.

Till today, ultrasound has been a widely used modality for predicting the difficult laparoscopic cholecystectomy in preoperative patients. Due to its several advantages like safety, wide availability, etc. it is preferred as an initial imaging study. Ultrasound shows stones in the gallbladder with a sensitivity and specificity of more than $90 \%$.

This study was undertaken to see if there is any correlation of Hs-CRP in assisting and improving the accuracy of ultrasonography in predicting difficult laparoscopy. This would help a surgeon to anticipate better a difficult cholecystectomy, better pre-operative counselling of patients, avoid excessive intraoperative manipulations, go for 
conversions early, reduce time of surgery and hence also minimise post-operative complications.

\section{MATERIALS AND METHODS}

This is an Observational Study. This was an original study done in Gauhati Medical College and Hospital in Guwahati, Assam. The study period was from $1 / 7 / 16$ to $30 / 6 / 16$. The study population comprised of 40 consecutive patients undergoing laparoscopic cholecystectomy after fulfilling the inclusion criteria. Patients having asymptomatic gallstones, acalculous cholecystitis, associated choledocholithiasis, malignancy, pregnancy, patients under steroid therapy/ local tissue irradiation, coagulopathies, previous operation of hepatobiliary system or upper GI surgery, any associated illness contraindicating cholecystectomy surgery and any associated illness leading to rise in CRP levels were excluded from the study. Informed consent was taken. Patients were also informed that in case of much difficulty, laparoscopy would be converted to open cholecystectomy. Cases were diagnosed as having cholecystitis due to cholelithiasis on the basis of ultrasonographic findings. The cases were prepared for laparoscopic cholecystectomy as per protocol followed in our institution. Relevant investigations were done. It included random blood sugar, complete haemogram, liver function test, renal function test, thyroid function test, chest x-ray, ECG, viral markers and ultrasonography of whole abdomen. The Hs-CRP level was determined pre-operatively at $6 \mathrm{hrs}$. and $12 \mathrm{hrs} .5 \mathrm{~mL}$ venous blood was collected in clot vials for transfer to biochemistry laboratory. The samples were analysed by the help of kit made by ROSS Co., Germany for COBAS INTEGRA 400 analyzer. At the time of admission, a thorough history, general and clinical examination was carried out and records were maintained. The age group was between 21 - 60 yrs.

\section{Surgical Procedure}

All the surgeries were performed by a consultant and done under general anaesthesia. Pneumoperitoneum is first created by using a Veress needle through an infraumbilical port. A total of 4 ports were used, 2 of $10 \mathrm{~mm}$ size and 2 of 5 $\mathrm{mm}$ size. Adhesion was released first. Dissection was done to make the Calot's triangle naked. The cystic artery and cystic duct was separately clipped and divided. The gallbladder was dissected off the gallbladder fossa using the monopolar cautery hook. At the completion of surgery, gallbladder was taken out using the epigastric port. The port was enlarged if needed. A saline lavage was done. Haemostasis was achieved. Drain was placed whenever clinically indicated. Ports were closed. When conversion was needed, it was done through right subcostal incision.

\section{Statistical Analysis}

Normally distributed continuous variables were compared using the paired t-test. Categorical variables were analysed using the Fisher exact test. For all statistical test, a p-value less than .05 was taken as significant. ROC analysis curve was plotted for values of Hs-CRP and its sensitivity for prediction of conversion.

\section{RESULTS}

\section{Patients' Demographic}

The total number of cases were 40 with 11 males and 29 females. Gender and age wise, these were comparable as the p value was found to be 1.000 using Fisher exact test. The male: female ratio was found to be $1: 2.6$. There were total of 8 cases in the age group of 21 - 30 yrs., 13 cases were in the age group of $31-40$ yrs., 16 in the age group of $41-50$ yrs. and 3 in 51 - 60 yrs. The mean age of incidence was found to be 39.65 yrs.

\section{Conversion to Open Cholecystectomy}

Out of 40 cases, 3 cases required conversion to open cholecystectomy. Among these 3 cases, 1 is male and 2 are females. $\mathrm{P}$ value was found to be 1.000 , which meant the difference is insignificant. The cases which required conversion were equally divided across the age group of 31 40, 41-50 and 51-60 yrs. The conversion in respect to age group and gender was found to be insignificant. However, to comment definitively we need a larger sample size.

\section{Conversion in Relation to USG}

For a thickened gallbladder, the cut-off value was taken to be $3 \mathrm{~mm}$ radiologically. Thickened gallbladder was found in 7 cases, out of which 3 cases required conversion to open cholecystectomy. The p-value was found to be 0.0035 , which reflects GB wall thickness as a significant risk factor. On USG 6 cases had adhesions present, out of which 3 cases needed conversion to open cholecystectomy. The presence of adhesion is a significant risk factor for conversion. In 5 cases Calot's triangle was observed to be narrowed radiologically, out of which 3 cases required conversion. The 'p' value was found to be 0.0010 . It reflects narrow Calot's triangle as a significant risk factor for conversion. The ' $p$ ' value of the difference in conversion rate among patients with single gallstone was found to be 0.498 using Fisher exact test. Therefore, the difference in conversion rate among patients having single or multiple calculi is not significant. In relation to a number of calculi in gallbladder seen radiologically, it was found that one case had single calculus and two cases had multiple calculi, among the three cases which required conversion. However, the ' $p$ ' value of the difference in conversion rate among patients with single gallstone and multiple gallstones was found to be 0.498 using Fisher exact test, which is not significant.

\section{Conversion in Relation to Hs-CRP}

The mean pre-operative value of Hs-CRP was found to be 9.68 $\mathrm{mg} / \mathrm{L}$. It increased to $21.88 \mathrm{mg} / \mathrm{L} 6 \mathrm{hrs}$. post-operatively and increased to $26.57 \mathrm{mg} / \mathrm{L} 12 \mathrm{hrs}$. post-operatively. The mean pre-operative value of Hs-CRP in cases which needed conversion was found to be $65.3 \mathrm{mg} / \mathrm{L}$ pre-operatively, 118.9 $\mathrm{mg} / \mathrm{L} 6 \mathrm{hrs}$. post-operatively, $129 \mathrm{mg} / \mathrm{L} 12 \mathrm{hrs}$. postoperatively. The difference in values of Hs-CRP between the cases who underwent laparoscopic cholecystectomy successfully and converted cases were found to be significant. The presence of high level of Hs-CRP gives a very good indication of ongoing inflammation in the body. Studies have shown that in case of inflammation, there is rise in level of CRP within $4-6$ hours. It reaches a peak value in two days and thereafter declines. Therefore, the values of Hs-CRP are also significant in understanding recovery, as it should decline after 2 to 3 days in absence of any infection postoperatively.

On using a cut-off value of Hs-CRP more than $20 \mathrm{mg} / \mathrm{L}$ pre-operatively, sensitivity was found to be $100 \%$ and 
specificity was $94.5 \%$. As the cut-off value was increased progressively up to $50 \mathrm{mg} / \mathrm{L}$, the sensitivity fell to $66.66 \%$ and specificity remained same at $100 \%$.

On combining USG parameters with different Hs-CRP cutoff values, it is observed as we increase the cut-off from 20 $\mathrm{mg} / \mathrm{L}$ to $50 \mathrm{mg} / \mathrm{L}$, the sensitivity remains same for $20 \mathrm{mg} / \mathrm{L}$, $30 \mathrm{mg} / \mathrm{L}$ and $40 \mathrm{mg} / \mathrm{dL}$. However, it decreases for $50 \mathrm{mg} / \mathrm{L}$. Both positive and negative predictive values were serially analysed with different cut-off points for Hs-CRP values. An improvement in positive predictive value is observed as the cut-off of Hs-CRP concentration is raised, while negative predictive value remained at 100 percent and fell to 97.36 percent for cut-off value of $50 \mathrm{mg} / \mathrm{dL}$. It is done between these two parameters only, as this was the aim of the study.

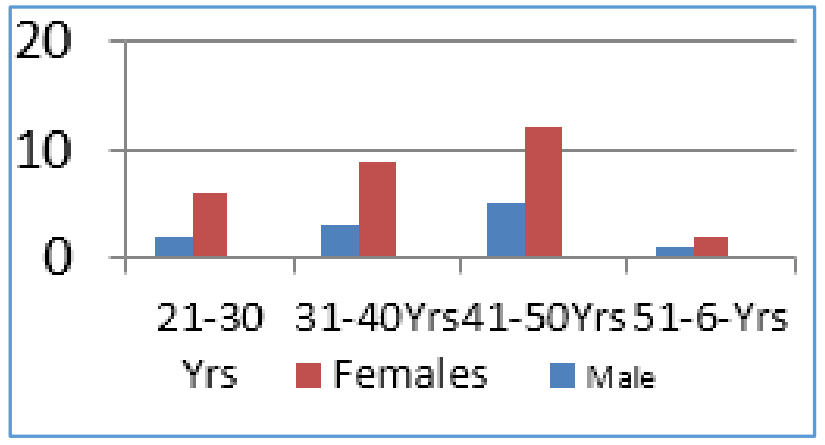

Figure 1. Age and Gender distribution of Study Group

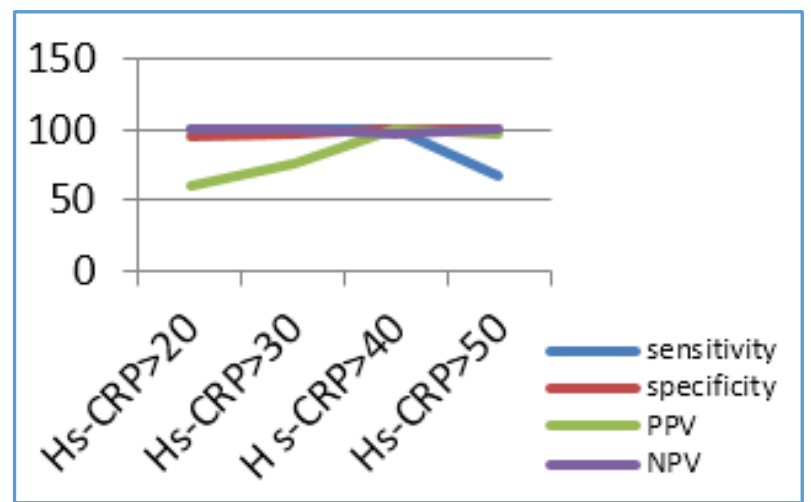

Figure 2. Showing the Specificity-Sensitivity Analysis for Conversion from LC to OC using different Cut-Off of Hs-CRP from more than $20 \mathrm{mg} / \mathrm{L}$ through $30 \mathrm{mg} / \mathrm{L}$, $40 \mathrm{mg} / \mathrm{L}, 50 \mathrm{mg} / \mathrm{L}$

\begin{tabular}{|c|c|c|c|}
\hline Group Parameter & N & Mean & $\begin{array}{c}\text { Standard } \\
\text { Deviation }\end{array}$ \\
\hline Cases- pre-op CRP & 40 & 9.68 & \pm 17.66 \\
\hline Cases- post-op at 6 hrs. CRP & 40 & 21.88 & \pm 31.2 \\
\hline Cases- post-op at 12 hrs. CRP & 40 & 26.57 & \pm 32.7 \\
\hline
\end{tabular}

Table 1. Mean and Standard Deviation of Values of Hs-CRP, Pre-operatively and Post-operatively at 6 Hrs. and 12 Hrs.

\begin{tabular}{|c|c|c|c|c|}
\hline Parameters & $\begin{array}{c}\text { Positive } \\
\text { Findings } \\
\text { on USG and } \\
\text { hs-CRP > 20 } \\
\text { mg/L }\end{array}$ & $\begin{array}{c}\text { Positive } \\
\text { Findings on } \\
\text { USG and } \\
\text { hs-CRP > 30 } \\
\text { mg/L }\end{array}$ & $\begin{array}{c}\text { Positive } \\
\text { Findings on } \\
\text { USG and } \\
\text { hs-CRP > 40 } \\
\text { mg/L }\end{array}$ & $\begin{array}{c}\text { Positive } \\
\text { Findings on } \\
\text { USG and } \\
\text { hs-CRP > } \\
\mathbf{5 0 ~ m g / L ~}\end{array}$ \\
\hline Sensitivity \% & $100 \%$ & $100 \%$ & $100 \%$ & $66.6 \%$ \\
\hline Specificity \% & $98.7 \%$ & $99.3 \%$ & $100 \%$ & $100 \%$ \\
\hline $\begin{array}{c}\text { Positive } \\
\text { predictive }\end{array}$ & $17.6 \%$ & $18.75 \%$ & $20 \%$ & $21.4 \%$ \\
\hline
\end{tabular}

\begin{tabular}{|c|c|c|c|c|}
\hline value $\%$ & & & & \\
\hline $\begin{array}{c}\text { Negative } \\
\text { predictive } \\
\text { value } \%\end{array}$ & $58.7 \%$ & $57.8 \%$ & $56.9 \%$ & $56.06 \%$ \\
\hline \multicolumn{2}{|c|}{ Table 2. Sensitivity, Specificity, PPV and NPV of } \\
Ultrasonography combined with different Pre-op \\
Cut-off Values of hs-CRP \\
\hline
\end{tabular}

Figure 3. ROC Curve

\begin{tabular}{|c|c|}
\hline \multicolumn{2}{|c|}{ Case Processing Summary } \\
\hline VAR00001 & Valid N (List Wise) \\
\hline Positive & 3 \\
\hline Negative & 37 \\
\hline \multicolumn{2}{|c|}{$\begin{array}{c}\text { Larger Values of the Test Result Variable(s) indicate } \\
\text { Stronger Evidence for a Positive Actual State }\end{array}$} \\
\hline
\end{tabular}

a. The positive actual state is 1.00 .

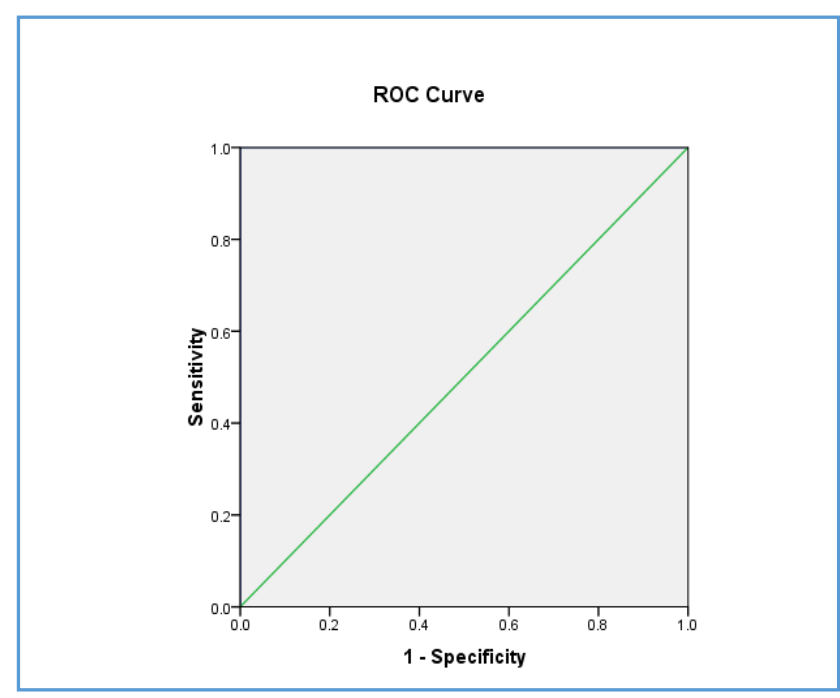

Area under the Curve

\begin{tabular}{|c|c|c|c|c|}
\hline \multicolumn{3}{|c|}{$\begin{array}{c}\text { Test Result Variable(s): } \\
\text { VAR00002 }\end{array}$} & \multicolumn{2}{|c|}{} \\
\hline \multirow{3}{*}{ Area } & $\begin{array}{c}\text { Std. } \\
\text { Error }\end{array}$ & $\begin{array}{c}\text { Asymptomatic } \\
\text { Sig. b }\end{array}$ & $\begin{array}{c}\text { Asymptomatic 95\% } \\
\text { Confidence Interval }\end{array}$ \\
\cline { 4 - 5 } & & $\begin{array}{c}\text { Lower } \\
\text { Bound }\end{array}$ & $\begin{array}{c}\text { Upper } \\
\text { Bound }\end{array}$ \\
\hline 1.000 & .000 & .004 & 1.000 & 1.000 \\
\hline \multicolumn{4}{|c|}{ a. Under the Non-Parametric Assumption } \\
\hline \multicolumn{4}{|c|}{ b. Null Hypothesis: True Area= 0.5 } \\
\hline
\end{tabular}

\begin{tabular}{|c|c|c|}
\hline \multicolumn{3}{|c|}{ Coordinates of the Curve } \\
\hline \multicolumn{2}{|c|}{ Test Result Variable(s): VAR00002 } \\
\hline $\begin{array}{c}\text { Positive if greater } \\
\text { than or equal to }\end{array}$ & Sensitivity & 1-Specificity \\
\hline .2000 & 1.000 & 1.000 \\
\hline 1.2500 & 1.000 & .919 \\
\hline 1.3650 & 1.000 & .892 \\
\hline 1.5150 & 1.000 & .865 \\
\hline 1.6500 & 1.000 & .838 \\
\hline 1.7500 & 1.000 & .811 \\
\hline 1.8500 & 1.000 & .784 \\
\hline 1.9500 & 1.000 & .730 \\
\hline 2.1000 & 1.000 & .703 \\
\hline 2.2500 & 1.000 & .676 \\
\hline 2.3500 & 1.000 & .622 \\
\hline
\end{tabular}




\begin{tabular}{|c|c|c|}
\hline 2.5300 & 1.000 & .595 \\
\hline 2.7300 & 1.000 & .568 \\
\hline 2.9500 & 1.000 & .514 \\
\hline 3.1500 & 1.000 & .432 \\
\hline 3.2500 & 1.000 & .405 \\
\hline 3.3500 & 1.000 & .378 \\
\hline 3.5000 & 1.000 & .351 \\
\hline 3.9500 & 1.000 & .324 \\
\hline 4.6500 & 1.000 & .297 \\
\hline 5.4500 & 1.000 & .270 \\
\hline 6.1500 & 1.000 & .243 \\
\hline 6.7500 & 1.000 & .216 \\
\hline 7.1500 & 1.000 & .189 \\
\hline 7.8500 & 1.000 & .162 \\
\hline 9.2000 & 1.000 & .135 \\
\hline 10.5000 & 1.000 & .108 \\
\hline 12.7500 & 1.000 & .081 \\
\hline 18.5000 & 1.000 & .054 \\
\hline 27.1000 & 1.000 & .027 \\
\hline 39.8000 & 1.000 & .000 \\
\hline 54.8500 & .667 & .000 \\
\hline 73.9500 & .333 & .000 \\
\hline 87.2000 & .000 & .000 \\
\hline \multicolumn{3}{|c|}{$\begin{array}{c}\text { a. The Smallest Cut-Off value is the Minimum observed Test } \\
\text { value Minus } 1 \text { and the Largest Cut-Off value is the } \\
\text { Maximum observed Test Value Plus } 1 \text {. All the other Cut-Off } \\
\text { values are the Averages of Two Consecutive ordered } \\
\text { observed Test Values }\end{array}$} \\
\hline
\end{tabular}

ROC curve reveals the highest sensitivity for Hs-CRP to be around $40 \mathrm{mg} / \mathrm{L}$ for conversion. This is in agreement with other studies done like Schafer $\mathrm{M}$ et al, Kam Wa et al, Weavers KP et al and Singh BA et al[21,22,23,24] where high values of CRP was found to be significant predictors for conversion.

\section{CONCLUSION}

The study was successful in establishing that when the preoperative values of Hs-CRP is correlated with ultrasonography findings, it can predict difficult cholecystectomy. It will help surgeons in making better judgement and better counselling of patients prior to surgery keeping comorbid conditions in view. Hs-CRP with ultrasound findings and experience of the surgeon will help in better selection of patients, thus reducing morbidity and mortality.

\section{REFERENCES}

[1] Cuschieri A, Dubois F, Mouiel J. The European experience with laparoscopic cholecystectomy. Am J Surg 1991;161(3):385-7.

[2] Alponat A, Kum CK, Koh BC, et al. Predictive factors for conversion of laparoscopic cholecystectomy. World J Surg 1997;21(6):629-33.

[3] Brunicardi FC. Gallbladder and extrahepatic biliary system. In: Corbett S. edr. Schwartz principles of surgery. $10^{\text {th }}$ edn. United States of America: McGrawHill 2015; p. 1319.

[4] De Mestral C, Roststein OD, Laupacis A, et al. Comparative operative outcomes of early and delayed cholecystectomy for acute cholecystitis: a populationbased propensity score analysis. Ann Surg 2014;259(1):10-5.

[5] Wu XS, Shi LB, Gu J, et al. Single-incision laparoscopic cholecystectomy versus multi-incision laparoscopic cholecystectomy: a meta-analysis of randomized clinical trials. J Laparoendosc Adv Surg Tech 2013;23(3):183-91.

[6] Wiebke EA, Pruitt AL, Howard T], et al. Conversion of laparoscopic to open cholecystectomy. An analysis of risk factors. Surg Endosc 1996;10(7):742-5.

[7] Rosen M, Brody F, Ponsky J. Predictive factors for conversion of laparoscopic cholecystectomy. Am J Surg 2002;184(3):254-8.

[8] Giger UF, Michel JM, Opitz I, et al. Risk factor for perioperative complications in patients undergoing laparoscopic cholecystectomy: analysis of 22,953 consecutive cases from the Swiss Association of Laparoscopic and Thoracoscopic Surgery database. J Am Coll Surg 2006;203(5):723-8.

[9] Das S. Biliary system. In: Das S. edr. A concise textbook of surgery. $6^{\text {th }}$ edn. Kolkata: 2010.

[10] Novacek G. Gender and gallstone diaease. Wien Med Wochenschr 2006;156(19-20):527-33.

[11] Ansari-Moghaddan A, Khoram A, Miri-Bonjar M, et al. The prevalence and risk factors of gallstones among adults in south-east of Iran: a population-based study. Glob J Health Sci 2016;8(4):60-7.

[12] Kanaan SA, Murayama KM, Merriam LT, et al. Risk factors for conversion of laparoscopic to open cholecystectomy. J Surg Res 2002;106(1):20-4. operatively at $6 \mathrm{hrs}$. and $12 \mathrm{hrs}$. Our study concludes that high Hs-CRP values pre-operatively predict conversion. The 
[13] Shapiro AJ, Costello C, Harkabus M, et al. Predicitng conversion of laparoscopic cholecystectomy for acute cholecystitis. J Soc Laparoendosc Surg 1999;3(2):12730.

[14] Lein HH, Huang CS. Male gender: risk factor for severe symptomatic cholelithiasis. World J Surg 2002;26(5):598-601.

[15] Kama NA, Kologlu M, Doganay M, et al. A risk score for conversion from laparoscopic to open cholecystectomy. Am J Surg 2001;181(6):520-5.

[16] Ibrahim S, Hean TK, Hol LS, et al. Risk factor for conversion to open surgery in patients undergoing laparoscopic cholecystectomy. World J Surg 2006;30(9):1698-704.

[17] Jethwani U, Singh G, Mohil RS, et al. Prediction of difficulty and conversion in laparoscopic cholecystectomy. OA Minimally Invasive Surg 2013;1(1):2.

[18] Tayeb M, Raza SA, Khan MR, et al. Conversion from laparoscopic to open cholecystectomy: multivariate analysis of pre-operative risk factors. J Postgrad Med 2005;51(1):17-20.
[19] Volkan G, Sulaimanov M, Gokhan C, et al. What necessitates the conversion to open cholecystectomy? A retrospective analysis of 5164 consecutive laparoscopic operations. Clinics (Sao Paulo) 2011;66(3):417-20.

[20] Chand P, Singh R, Singh B, et al. Pre-operative USG as a predictor of difficult laparoscopic cholecystectomy that requires conversion to open procedure. Niger J Surg 2015;21(2):102-5.

[21] Schafer M, Krahenbuhl L, Buchler MW. Predictive factors for the type of surgery in 'acute cholecystitis. Am J Surg 2001;182(3):291-7.

[22] Wevers KP, van Westreenen HL, Patijn GA. Laparoscopic cholecystectomy in acute cholecystitis: C-reactive protein level combined with age predicts conversion. Surg Laparosc Endosc Percutan Tech 2013;23(2):163-6.

[23] Mok KWJ, Goh YL, Howell LE, et al. Is C reactive protein the single most useful predictor of difficult laparoscopic cholecystectomy or its conversion? A pilot study. J Minim Acess Surg 2016;12(1):26-32.

[24] Arora BS, Sen P, Singh RK, et al. Hs-CRP levels as predictor of difficult laparoscopic cholecystectomycurrent status evaluation experience in a teaching institution. Int Surg J 2017;4(4):1345-9. 